\title{
A study on customer based brand equity (CBBE) of refined sunflower cooking oil in Tamil Nadu
}

\section{P. BALAJI}

Received : 01.02.2015; Revised : 12.02.2015; Accepted : 27.02.2015

\begin{abstract}
Sunflower oil has a balanced and rich nutrients composition. A large amount of vitamin E and fatty acids (omega 6) makes the oil effective for both internal and external usage. This study aims to identify the factors that influenced the customer based brand equity of branded sunflower refined cooking oils in Tamil Nadu. Chennai and Coimbatore cities were considered for the study. The total sample size was 60 women respondents. Majority of the respondents were aged > 40 years, literate, employed and earned up to Rs. 2500 per month about 95 per cent of the customers were willing to purchase the same brand XX. The perceived quality, brand awareness and brand loyalty were the factors influenced the customer based brand equity for the sunflower refined cooking oils in Tamil Nadu.
\end{abstract}

KEY WORDS : Brand equity, Brand awareness, Sunflower oil, brand loyalty, Willingness to purchase

How to cite this paper : Balaji, P. (2015). A study on customer based brand equity (CBBE) of refined sunflower cooking oil in Tamil Nadu. Internat. J. Com. \& Bus. Manage, 8(1) : 36-41.

\section{AUTHOR FOR CORRESPONDENCE}

P. BALAJI, Department of Agricultural and Rural Management, Tamil Nadu Agricultural University, COIMBATORE (T.N.) INDIA

Email: pbalaji@tnau.ac.in 